\title{
Preeclampsia and pre term low birth weight babies: Possible role of periodontal infections: A comprehensive review
}

\author{
Annapurna Ahuja ${ }^{1 *}$, Vipin Ahuja ${ }^{2}$, Aiswarya Mishra ${ }^{3}$, Ruchi Minz ${ }^{4}$, Sharmila $^{5}$ \\ ${ }^{\mathbf{1}}$ Professor and HOD, ${ }^{2}$ Professor, ${ }^{3-5}$ Postgraudate, ${ }^{\mathbf{1} 3-5}$ Dept. of Periodontology \& Implantology, ${ }^{2}$ Dept. of Pedodontics and Preventive \\ Dentistry, Hazaribag College of Dental Science \& Hospital, Hazaribagh, Jharkhand, India
}

*Corresponding Author: Annapurna Ahuja

Email: annapurna.ahuja@yahoo.com

\begin{abstract}
s
Periodontitis is an inflammatory disease affecting supportive tissues of the teeth, leading to progressive destruction of connective tissue attachment and the alveolar bone. This destruction is characterized by the formation of a periodontal pocket. Because of its chronic inflammatory infectious nature, periodontitis has been considered a systemic exposure implicated with causative agent in variety of systemic diseases and condition. Recent findings have suggested that periodontal diseases are associated with a higher risk of cardiovascular diseases, atherosclerosis and adverse pregnancy outcomes, such as preterm birth and low birth weight and preeclampsia.
\end{abstract}

Keywords: Periodontitis, Preelampsia, Preterm low birth weight babies.

\section{Introduction}

Periodontitis is an inflammatory disease affecting supportive tissues of the teeth, leading to progressive destruction of connective tissue attachment and the alveolar bone. This destruction is characterized by the formation of a periodontal pocket.

Because of its chronic inflammatory infectious nature, periodontitis has been considered a systemic exposure implicated with causative agent in variety of systemic diseases and condition. Recent findings have suggested that periodontal diseases are associated with a higher risk of cardiovascular diseases, atherosclerosis and adverse pregnancy outcomes, such as preterm birth and low birth weight. ${ }^{1}$ and preeclampsia. ${ }^{2}$

Preeclampsia is a multi factorial disorder affecting approximately $10 \%$ of pregnancies and contributes significantly to maternal and perinatal morbidity and mortality. ${ }^{2}$ It usually occurs after 20 weeks of gestations. It is characterized by abnormal vascular response to placentation, reduced organ perfusion, vasospasm, activation of coagulation system, inflammatory like response, oxidative stress, and some perturbation in volume and blood pressure control, affecting the placenta, kidney, liver, and brain. Preeclampsia is determined by maternal blood pressure elevation accompanied by proteinuria. ${ }^{3}$

What is Preeclampsia and pre term low birth weight baby?: Preeclampsia can be defined as blood pressure $>140 / 90 \mathrm{~mm}$ of $\mathrm{Hg}$ on two separate occasion after 20 week of gestationand at least $1+$ proteinuria. $^{2}$

The World Health Organization defines preterm birth as any live birth at less than 37 weeks of gestation. Delivery at less than 32 weeks is termed very preterm, and delivery at less than 28 weeks, as extremely preterm. The majority of preterm births are also low birth weight. The international definition of low birth weight adopted by the Twenty-ninth World Health Assembly in 1976 is a birth weight of "less than 2500 g." ${ }^{5}$

\section{Etiology of preeclampsia}

Periodontal infections increases the burden of endo toxins, inflammatory cytokines on vessels ${ }^{4}$ Effects on Feto Placental unit blood vessels leading to Atherosclerotic lesions of the spiral arteries ${ }^{4}$ causing Ischemia, ${ }^{3}$ Oxidative and inflammatory vascular damage, ${ }^{4}$ Endothelial damage in the placental vascular bed ${ }^{4}$ and Preeclampsia ${ }^{4}$

Risk factors for preterm low birth weight babies ${ }^{6}$

1. Primary present before pregnancy, 2. Secondary develop during pregnancy

Possible role of periodontitis in causing pre term low birth weight babies ${ }^{7}$ :

Tissue invading $\mathrm{gm}$ - ve bacteria release endotoxins which triggers release of inflammatory mediators like cytokine and PGE 2. Inflammatory Mediators are increased in Amniotic Fluid as well. Causing premature rupture of the membrane.

Table 1: Studies associating role of periodontal infection and pre mature birth/ preeclampsia

\begin{tabular}{|l|l|l|}
\hline \multicolumn{1}{|c|}{ Author and year } & \multicolumn{1}{|c|}{ Study design/population } & \multicolumn{1}{c|}{ Conclusion } \\
\hline Collins et al 1994 & $\begin{array}{l}\text { Hamster model. which utilized a localized, } \\
\text { non-systemic (non-disseminating) infection } \\
\text { with periodontal pathogenic bacterium } \\
\text { Porphyromonas gingivalis. }\end{array}$ & $\begin{array}{l}\text { Increases in PGE2and TNF } \alpha \text { were observed } \\
\text { which appeared to be associated with reduced } \\
\text { fetal birth weight }\end{array}$ \\
\hline Dasanayake 19989 & 55 pairs of women & $\begin{array}{l}\text { Logistic regression indicated mothers } \\
\text { With healthy gingiva were at lower risk for low } \\
\text { birth weight infants (odds ratio=0.3). }\end{array}$ \\
\hline
\end{tabular}




\begin{tabular}{|c|c|c|}
\hline Hillier et al $1993^{10}$ & 50 women with preterm labour & $\begin{array}{l}\text { Reported that the mean concentration of } \\
\text { amniotic fluid IL- } 6 \text { was higher when delivery } \\
\text { occurred before } 34 \\
\text { Week's gestational age. }\end{array}$ \\
\hline $\begin{array}{l}\text { Lu1's } \quad \text { Ota'vio } \\
\text { Miranda } \\
2006^{11}\end{array}$ & 588 women & $\begin{array}{l}\text { Maternal periodontitis was determined to be } \\
\text { associated with an increased risk of } \\
\text { preeclampsia. }\end{array}$ \\
\hline Jefcoat et al $2003^{12}$ & 1313 women & $\begin{array}{l}\text { Periodontal disease association with preterm } \\
\text { low birth weight babies }\end{array}$ \\
\hline $\begin{array}{l}\text { Boggess KA et al } \\
2005^{13}\end{array}$ & - & $\begin{array}{l}\text { When fetal exposure to oral microorganisms } \\
\text { occur, the risk of preterm delivery increases } 2 \\
\text { fold, but when there is an attendant fetal } \\
\text { inflammatory response the risk increases } 4-7 \\
\text { fold. }\end{array}$ \\
\hline Offenbacherr $1996^{14}$ & $\begin{array}{l}124 \text { pregnant or postpartum } \\
\text { Mothers. }\end{array}$ & $\begin{array}{l}\text { Mothers with preterm or low birth-weight } \\
\text { babies had significantly worse periodontal } \\
\text { disease than those giving birth to normal } \\
\text { weight babies. They suggested a role of } \\
\text { cytokines in the mechanism for preterm low } \\
\text { birth weight babies. }\end{array}$ \\
\hline
\end{tabular}

Table 2: Role of cytokines in preterm low birth weight babies studies:

\begin{tabular}{|l|l|}
\hline Romero et al $1993^{15}$ & $\begin{array}{l}\text { Amniotic fluid IL-6 is a reliable marker of intrauterine infection in women with } \\
\text { premature rupture of membranes. }\end{array}$ \\
\hline Hillier et al $1993^{16}$ & $\begin{array}{l}\text { Reported that the mean concentration of amniotic fluid IL-6 was higher when } \\
\text { delivery occurred before 34 weeks gestational age. }\end{array}$ \\
\hline
\end{tabular}

Table 3: Risk factors for preterm low birth weight babies

\begin{tabular}{|c|c|}
\hline Modifiable & Non modifiable \\
\hline Low socio economic conditions & Genetics \\
\hline Smoking & Multifetal pregnancies \\
\hline Diet and nutrition & Previous pre term birth \\
\hline Systemic diseases & Abnormal placenta \\
\hline Domestic violence & Young age pregnancy \\
\hline Stress / depression & Abnormal fetal position \\
\hline Preeclampsia & Abnormal fetus \\
\hline Periodontal diseases & Systemic disease/syndromes \\
\hline
\end{tabular}

Diagnostic factors of preeclampsia/ pre term low birth weight babies

Blood pressure $>140 / 90 \mathrm{~mm}$ of $\mathrm{Hg}$ at 20 weeks of gestation Proteinuria, quantification of protein excretion over 24 hours is the gold standard method.

The international definition of low birth weight adopted by the Twenty-ninth World Health Assembly in 1976 is a birth weight of "less than 2500 g." 5

\section{Conclusion}

Because of its chronic inflammatory infectious nature, periodontitis has been considered a systemic exposure implicated with causative agents in a variety of systemic illnesses. Recent findings have suggested that periodontal disease is associated with a higher risk of preeclampsia and pre term low birth weight babies.

Associations between preeclampsia, preterm low birth weight babies and periodontitis should be interpreted with discretion, because the etiology of both events is likely multifactorial. It is important to emphasize that primary healthcare services must be proficient to diagnose and manage periodontal disease all through pregnancy. Managing periodontal disease may represent a novel strategy to reduce the incidence and/or complications from adverse pregnancy outcomes.

\section{Source of funding}

None.

\section{Conflict of interest}

None.

\section{References}

1. Lopez R. Periodontal disease, preterm birth and low birth weight. Evid Based Dent 2005;6:90-1. 
2. Boggess K, Alieff S Murtha AP, Moss K, Eck J, Offenbacher $\mathrm{S}$. Maternal periodontal disease is associated with an increased risk for preeclampsia. Obstet Gynecol 2003;101;227-31.

3. Sibai B, Dekker G, Kupfermic M. Preeclampsia. Lancet 2005;365:785-99.

4. Dekker G A, Sibai BM. The immunology of preeclampsia. Semin Perinatol 1999;23:24-33.

5. World Health Organization. The incidence of low birth weight: a critical review of available information. World Health Statistic Q 1980;33:197-224.

6. Goffinet F. Primary predictors of preterm labour. Br J Obstet Gynaecol 2005;112(Suppl 1):38-47.

7. Offenbacher S, Jared HL, O'Reilly PG. Potential pathogenic mechanisms of periodontitis associated pregnancy complications. Ann Periodontol 1998;3:233-50.

8. Collins JG, Windley HW III, Amold RR, Offenbacher S. Effects of a Porphyromonas gingivalis infection on inflammatory mediator response in pregnancy outcome in hamsters. Infect Immun 1994;62:4356-61.

9. Dasanayake AP. Poor periodontal health of the pregnant woman as a risk factor for low birth weight. Ann Periodontol 1998;3:206-12.

10. Hillier SL, Witkin SS, Krohn MA, Watts DH, Kiviat NB, Eschenbach DA. The relationship of amniotic fluid cytokines and preterm delivery, amniotic fluid infection, histologic chorioamnionitis and chorioamnion infection. Obstet Gynecol 1993;81:941-8.

11. Lu1's Ota'vio Miranda Cota. Association between maternal periodontitis and an increased risk of preeclampsia. $J$ Periodontol 2006;77:2063-9.

12. Jefcoat MK, Hauth J C, Geurs NC. Periodontal disease and preterm birth: Results of pilot interventional study. $J$ Periodontal 2003;74;1214-8.
13. Boggess KA, Moss K, Madionas P, Murtha AP, Beck J, Offenbacher S. Fetal immune response to oral pathogens and risk of preterm birth. Am J Obstet Gynecol 2005;193:1121-6.

14. Offenbacher $S$, Katz V, Fertik G. Periodontal infection as a possible risk factor for preterm low birth weight. J Periodontol 1996;67(10suppl):1103-13.

15. Romero R, Yoon BH, Mazoa M, Gomez R. The diagnosis and prognostic value of amniotic fluid white blood cell count, glucose, interleukin 6 , and gram stain in patients with preterm labour and intact membranes. Am J Obstet Gynecol 1993:169;805-16.

16. Hillier SL, Witkin SS, Krohn MA, Watts DH, Kiviat NB, Eschenbach DA. The relationship of amniotic fluid cytokines and preterm delivery, amniotic fluid infection, histologic chorioamnionitis and chorioamnion infection. Obstet Gynecol 1993:81;941-8.

How to cite: Ahuja A, Ahuja V, Mishra A, Minz R, Sharmila. Preeclampsia and pre term low birth weight babies: Possible role of periodontal infections: A comprehensive review. IP Int $J$ Periodontol Implantol 2020;5(1):16-8. 